\title{
Lopinavir/ritonavir-based second line antiretroviral treatment in children at National Pediatric Hospital, Phnom Penh, Cambodia
} Sophan Sam ${ }^{* 1}$, Vibol Ung ${ }^{1}$, Chantheany Huot ${ }^{1}$, Bunnthy Chan ${ }^{1}$, Kdan Yuvatha ${ }^{1}$, Christian Courpotin ${ }^{2}$, Guillaume Adam ${ }^{2}$, Sopheak Ngin ${ }^{3}$, Eric Nerrienet ${ }^{3}$ and Y Meng Chhour ${ }^{1}$

Address: ${ }^{1}$ National Pediatric Hospital, Phnom Penh, Cambodia, ${ }^{2}$ French Red Cross, Paris, France and ${ }^{3} \mathrm{HIV} /$ Hepatitis Laboratory, Institute Pasteur, Phnom Penh, Cambodia

* Corresponding author

from Fifth Dominique Dormont International Conference. Mother-to-child transmitted viral diseases: from transmission to children care Paris, France. 26-28 March 2009

Published: 22 July 2009

Retrovirology 2009, 6(Suppl I):O25 doi:I0.II86/I742-4690-6-SI-O25

This abstract is available from: http://www.retrovirology.com/content/6/SI/O25

(C) 2009 Sam et al; licensee BioMed Central Ltd.

\section{Background}

Cambodia has scaling up a large national ART program using $1^{\text {st }}$ line therapy ( $\mathrm{d} 4 \mathrm{~T}$ or $\mathrm{AZT}+3 \mathrm{TC}+\mathrm{NVP}$ or $\left.\mathrm{EFV}\right)$. According to NCHADS, as December $31^{\text {st }} 2008,3,067$ children were on HAART in Cambodia, 746 of them were followed-up in Child Health Improvement Clinic (CHIC) at the National Pediatric Hospital, (NPH), with French Red Cross technical support. Fifthy-three out of 746 already switched on LPVr-based $2^{\text {nd }}$ line regimen.

\section{Objective}

The aim of this study was to evaluate virological and immunological outcomes of these children on second line.

\section{Methods}

Retrospective analysis based on data and medical records from a cohort followed at CHIC to 31 $1^{\text {st }}$ December 2008 was conducted. Patients meeting the Cambodian National Guidelines for the Use of Pediatric ART for treatment failure were evaluated. First line treatment failure was confirmed based on clinical and immunological failure and/or virological failure. Plasma viral load has been assessed by HIV RNA real time PCR using $2^{\text {nd }}$ generation ANRS Kit. Genotypic resistance analysis was done at Institute Pasteur according to ANRS algorithm (v.sep.07).

\section{Results}

$53 / 746$ patient $(7.1 \%)$ switched to $2^{\text {nd }}$ line were enrolled in this study (33.9\% were females). Median age was 10.9 years (2.1-17.9). Median duration on the $1^{\text {st }}$ line was 2.2 years (0.6-6.3). Median of CD4 percentage at switch was $8.0 \%$ and VL was $5.1 \log _{10}(4.0-6.3)$ with +/- clinical failure. At switch, 38/53 patients were tested for HIV drug resistance. HIV Drug resistance analysis revealed that $97.3 \%(37 / 38)$ children were resistant to $\mathrm{NVP} / \mathrm{EFV}$, $78.9 \%$ to $\mathrm{AZT} / \mathrm{d} 4 \mathrm{~T} / 3 \mathrm{TC} / \mathrm{FTC}, 47.3 \%$ to $\mathrm{ABC} / \mathrm{ddI}$, and $10.5 \%$ to TDF. Thirty-six of 53 patients $(67.9 \%)$ received standard $2^{\text {nd }}$ line regimen (ABC/ddI/LPV/r), 9 (16.9\%) received 3TC/TDF/LPV/r, 4 (7.5\%) were on 3TC/AZT/ $\mathrm{LPV} / \mathrm{r}$, and $2(3.7 \%)$ on $3 \mathrm{TC} / \mathrm{ddI} / \mathrm{LPV} / \mathrm{r}$. At evaluation, median duration on $2^{\text {nd }}$ line was 1.0 years $(0.1-3.3)$. Median CD4\% gain on $2^{\text {nd }}$ line regimen were $13.0 \%$ (1$31 \%)$ at $\mathrm{M} 6(\mathrm{n}=34) ; 17.0 \%(1-33)$ at $\mathrm{M} 12(\mathrm{n}=27)$; $19.5 \%(12-29)$ at $\mathrm{M} 18(\mathrm{n}=12) ; 20.0 \%(16-32)$ at $\mathrm{M} 24$ $(\mathrm{n}=7)$; and $18.0 \%(17-28)$ at M30 $(\mathrm{n}=3)$. Children who achieved undetectable VL $\left(\mathrm{VL}<2.4 \log _{10}\right)$ at $\mathrm{M} 2$ were $71.0 \%(\mathrm{n}=38) ; 85.2 \%$ at M6 $(\mathrm{n}=34) ; 88 \%$ at $\mathrm{M} 12(\mathrm{n}=$ $25), 77.7 \%$ at $M 18(\mathrm{n}=9) ; 85.5 \%$ at $M 24(\mathrm{n}=7)$ and $100 \%$ at $\mathrm{M} 30(\mathrm{n}=3)$.

\section{Conclusion}

These preliminary data on Cambodian HIV infected children on $\mathrm{LPV}_{/ \mathrm{r}}$-based second line HAART regimen indicated good virological/immunological responses 